\title{
Potret Organisasi Jurnalis Pasca Orde Baru di Daerah Istimewa Yogyakarta
}

\author{
Masduki \\ Dosen Program Studi Ilmu Komunikasi, Universitas Islam Indonesia
}

\begin{abstract}
:
Association of journalists is one of the press freedom pillars. Up to 15 years after the collapsed of New Order regime, there has been no comprehensive studies related to the performance of journalist's association in maintaining the press freedom, professionalism of their members and engagement in public issue advocacies. This paper describes the results of research on the portrait of journalist organizations in Yogyakarta, using qualitative method throughout the months of May-June 2015. This research found that two models: formal and nonp-formal associations existed, with the tendency of different solidity and independence. In addition to the lack of membership loyalty and funding, internal ego of the organization in carrying out the mission is a serious problem in the
\end{abstract} future.

Keyword: Organization, Journalist, Independence, PWI, AJI, IJTI

\section{Pengantar}

Di masa rezim Orde Baru (19961998), politik monoloyolitas diterapkan, dimana organisasi jurnalis bersifat tunggal: Persatuan Wartawan Indonesia, sedangkan organisasi jurnalis yang lain dilarang. Di masa tersebut, PWI hidup dari fasilitas negara, gedung kantor sekretariat, pengesahan anggota, hingga pendanaan operasional. Pasca runtuhnya rezim Orba, kebijakan ini ikut runtuh, keberadaan organisasi jurnalis berkembang bak jamur di musim hujan. Namun, belum ada kajian yang membahas perkembangan terkini, belum ada publikasi akademik yang menggunakan pendekatan komparatif kinerja organisasi jurnalis dikaitkan isu isu krusial seperti kebebasan pers dan perlindungan profesi. Apakah telah terjadi perubahan visi, misi, dan pendekatan dalam menjalankan peran? Perubahan sangat mungkin terjadi setelah 15 tahun lebih kran kebebasan pers dibuka, dan kebebasan berorganisasi bagi jurnalis sebagaimana telah diatur UU 40/1999 tentang Pers.

Pada dasarnya, organisasi jurnalis yang sehat dengan sendirinya akan mencerminkan kemandirian/otonomi pers, independensi dari tekanan korporasi dan Negara. Sehat tidaknya organisasi pers bergantung beberapa indikator, yang utamanya sejauh mana independensi organisasi itu sendiri dari intervensi kekuatan eksternal. Otonomi ini sejalan dengan prinsip universal profesi jurnalis dalam menjalankan fungsi kontrol sosial merujuk etik jurnalisme Bill Kovach. Dalam review terbaru untuk buku ini, Sonia Peter menyebut prinsip etis ke to dari Kovach berupa tanggungjawab ganda jurnalis sebagai editor dan konsumen, tetap tidak merubah bahwa fondasi etik jurnalisme adalah independensi (Peter, 2013). 
Dalam kerangka profesionalisme, organisasi jurnalis berfungsi membangun kesadaran kritis jurnalis dalam menjalankan tugas sebagai buruh profesional, melalui berbagai aktifitas pelatihan, advokasi dan penyadaran jati diri yang konsisten, ideologis dan praksis. Pada saat yang sama, organisasi harus mampu memproteksi jurnalis dari tekanan eksternal yang dapat membelenggu otonomi, antara lain budaya amplop.

Di tengah tuntutan peran dan kontribusi organisasi jurnalis terhadap pemberdayaan anggotanya, fakta menunjukan bahwa database organisasi jurnalis di Indonesia yang lengkap, termasuk di Yogyakarta belum tersedia. Padahal data ini akan menjadi cermin kehidupan pers suatu negara. Database yang lengkap terkait sejarah, format organisasi, sistem keanggotaan, manajemen sektor keuangan dan bentuk kegiatan penting untuk mengukur organisasi hidup dan bertahan, serta mampu menjadi motor penggerak kebebasan pers.

Dewan Pers hingga 2015 baru mengakui 3 organisasi jurnalis: PWI, Aliansi Jurnalis Independen (AJI) dan Ikatan Jurnalis Televisi Indonesia (IJTI) berdasarkan survei indikator organisasi jurnalis yang telah dibuat sebelumnya. Bagaimana dengan profil dan keberadaan organisasi jurnalis diluar ketiga institusi tersebut?

Meminjam pendapat peneliti senior Australia, David T Hill, indikator kehidupan pers bisa dilihat pada tiga sektor: jurnalis itu sendiri, institusi media dan organisasi jurnalis yang saling sinergis, independen dan kuat. Di masa Orba, pers berbulan madu dengan kekuasaan otoriter dan pasca Orba, pers harus mengkoreksi pilihan itu. Oleh karenanya, mengetahui potret organisasi jurnalis yang dimulai dari Yogyakarta penting, bukan hanya memastikan ada tidaknya organisasi itu, tetapi mengukur kemampuannya sebagai pilar kehidupan pers lokal dan nasional yang kuat sebagai aktor keempat demokrasi.

Berdasarkan latar belakang permasalahan di atas, maka tulisan ini akan menguraikan seputar bagaimana profil organisasi jurnalis di DIY, kontribusi organisasi terhadap penguatan profesionalisme jurnalis dan advokasi isu kebebasan pers? Bagaimana relasi antar kelompok organisasi pers dengan kelompok lain yang beririsan, misalnya dengan aktifis LSM ataupun aktifis isu-isu publik lain? Tulisan ini berdasarkan riset yang dilakukan sepanjang bulan Mei-Juli 2015, dan bertujuan untuk memahami dan menganalisis kondisi aktual organisasi jurnalis dalam konteks peran aktual, dan merumuskan rekomendasi pengembangan lebih lanjut pada aspek peran, kelembagaan dan tata kelola organisasi di Yogyakarta.

Penelitian menggunakan metode kualitatif. Pengumpulan data dengan cara observasi, wawancara dan dokumentasi. Metode pemilihan narasumber dengan cara purposif (Sutopo (2002), peneliti memilih informan yang dianggap mengetahui informasi dan permasalahan secara mendalam, dan dapat dipercaya untuk menjadi sumber data. Adapun informan yang dianggap tepat adalah orang-orang yang mengetahui permasalahan dan informasi secara mendalam mengenai kinerja dan pelaksanaan program-program organisasi jurnalis. Peneliti memilih 6 organisasi atau perkumpulan para jurnalis di DIY yang dinilai mewakili gambaran organisasi jurnalis pasca Orde Baru. Penulis juga menggunakan teknik snowball sampling yaitu apabila informasi dari informan pertama terbatas, maka informasi lainnya digali dari informan yang ditunjuk lebih lanjut oleh informan pertama.

\section{Kebebasan Pers}

Kebebasan pers diartikan dalam banyak pendekatan oleh para ahli. Kebebasan pers berakar kuat pada kebebasan berekspresi. Dalam UU 9/1998 tentang Kebebasan Berpendapat di muka umum, ditegaskan bahwa setiap warga Negara bebas menyampaikan pendapat lisan, tulisan dan atau melalui ruang terbuka seperti pawai, mimbar bebas, demonstrasi dan bentuk serupa seperti ritual budaya. Pasal 2 UU ini 
menyebutkan warga negara, secara perorangan atau kelompok, bebas menyampaikan pendapat sebagai perwujudan hak dan tanggung jawab berdemokrasi dalam kehidupan berbangsa dan bernegara.

Setiap warga Negara yang menyampaikan pendapat berhak atas perlindungan hukum. Pada pasal 6 UU diatas disebutkan, warga negara yang menyampaikan pendapat di muka umum bérkewajiban dan bertanggung jawab menghormati hak-hak dan kebebasan orang lain dan menghormati aturanaturan moral yang diakui umum. Indonesia termasuk salah satu Negara dengan indeks kebebasan pers cukup baik, tergolong 100 besar dunia yang bermakna telah eksisnya kebebasan berekspresi melalui media massa.

Era kebebasan pers di Indonesia ditandai enam perkembangan yang disebut Tamagola (1999) sebagai fenomena delegitimasi rezim Orba, 19961998:

(1) Munculnya krisis ekonomi secara nasional dan krisis kepercayaan terhadap rezim Soeharto sehingga setiap gerak dan jargon pembangunan yang muncul dari kabinet cenderung disikapi skeptis. Rezim Soeharto dan kronikroninya kewalahan menghadapi melorotnya nilai tukar rupiah yang diikuti krisis harga Sembako. Kebijakan karitatif seperti program jaring pengaman sosial (JPS) yang tidak merata dan dikorup memicu gelombang protes sosial.

(2) Munculnya sistem komunikasi alternatif dalam masyarakat, melibatkan pers underground, rumors, jaringan komunikasi interpersonal, internet yang menjadi "teknologi pembebasan" dan secara internasional mampu membangun solidaritas anti-KKN, menyeimbangkan arus informasi yang sebelumnya didominasi kekuatan pemodal dan penguasa "istana". Salah satu situs yang tercatat fenomenal adalah Apakabar yang beroperasi di Amerika Serikat.

(3) Munculnya aktifisme, resistensi jurnalis serta organisasi alternatif diluar PWI yang telah dikooptasi rezim Orde Baru seperti AJI dan PWI Reformasi. Organisasi pers mahasiswa bergerak lebih agresif membaur dengan elemen gerakan jalanan.

(4) Munculnya politik bahasa tandingan dengan frame yang memiliki bobot pesona spiritual. Dari pembangunan ke demokrasi, HAM, Keadilan. Pembangunan menjadi istilah yang negatif akibat kegagalan pengusung istilah itu mewujudkan pemerataan kesejahteraan dan yang terjadi sentralisasi kendali ekonomi dan monopolisasi yang memicu gerakan perlawanan anti pelanggaran HAM.

(5) Resistensi pembaca dan pemirsa melalui pengembangan etnometodologi (kemampuan reading between the line atau reading between the lies). Kemampuan masyarakat mencurigai berbagai kepentingan sepihak dibalik setiap pernyataan bombastis yang dikemukakan aparat pemerintah disemua tingkatan (Masduki, 2004).

Bagaimana

perkembangan mutakhir media di Indonesia paska 1998? Telah terjadi pergeseran yang signifikan seperti digambarkan dalam tabel berikut: 
Organisasi profesi jurnalis tèrmasuk dalam kategori organisasi dalam pers, seperti diatur pasal 5 ayat 1 UU No. 40/1999 bahwa: "Organisasi pers adalah organisasi wartawan dan organisasi perusahaan pers". Ada banyak alasan - mengapa organisasi jurnalis perlu dibentuk. Salah satu yang kerapkali dituliskan dalam visi dam misi organisasi jurnalis adalah untuk memperjuangkan hak sérta menyuarakan kepentingan wartawan baik dalam proses negosiasi dengan pemerintah dan pemodal. Visi dan misi ini melampaui fungsi tradisional organisasi yang hanya berkutat pada isu teknis organisasi.

Ashadi Siregar lebih lanjut mengemukakan pentingnya organisasi profesi. Organisasi profesi jurnalistik membantu institusi media dalam mengembangkan pelaku profesi yang berada di dalamnya. Sebagian dari beban kerja pemimpin redaksi untuk membina personil di medianya baik bidang teknis maupun etis diambil alih organisasi profesi. Organisasi profesi jurnalis dibutuhkan karena berperan mengeluarkan kode etik jurnalistik sebagaimana amanat UU40/1999. Pembinaan etika personel jurnalis diletakkan sebagian pada organisasi yang . menyediakan kemungkinan mengembangkan kapasitas teknis profesional anggotanya dan memantau pelaksanaan kode etik jurnalistik (Siregar, 2000).

Organisasi profesi jurnalis pertama didirikan di Indonesia adalah Persatuan Wartawan Indonesia (PWI) pada tanggal 9 Februari 1946, yang kemudian membuat kode etik jurnalistik pada tahun 1955. PWI satu-satunya organisasi kewartawanan yang wajib diikuti oleh semua wartawan di Indonesia sampai tahun 1999, sekalipun AJI sudah berdiri sejak tahun 1994. Berdasarkan UU No. 40/1999 tentang Pers, yang diundangkan pada 23 September 1999, disebutkan bahwa organisasi profesi wartawan boleh bebas didirikan sehingga monopoli PWI sebagai orgánisasi kewartawanan sudah tidak ada.
Disisi lain, UU ini juga tidak mengatur kewajiban jurnalis masuk menjadi anggota organisasi jurnalis.

\section{Standar Organisasi Jurnalis}

Jurnalis dan organisasi jurnalis adalah dua sisi mata uang, makin besar jumlah jurnalis di suatu kawasan, makin berpeluang dan penting organisasi jurnalis. Semakin kuat organisasi jurnalis, akan menunjukkan kuatnya eksistensi jurnalis di suatu kawasan. Indeks kebebasan pers yang dilakukan setiap tahun oleh Freedom House, antara lain mengukur kebebebasan berorganisasi di kalangan jurnalis, seiring dengan kebebasan kerja dari jurnalis. Prakteknya, kebebasan pers di Indonesia telah melahirkan ragam organisasi jurnalis yang eksistensinya telah diproteksi oleh UU dan tidak lagi bersifat tunggal.

Pasca rezim Orde Baru runtuh tahun 1998, jumlah organisasi jurnalis membludak, termasuk di Yogyakarta. Jika dibuat pemetaan, maka sedikitnya terdapat dua tipologi jurnalis berdasarkan tingkatan geografis: yaitu Pertama, organisasi yang berskala nasional, antara lain Persatuan Wartawan Indonesia, Aliansi Jurnalis Independen dan Ikatan Jurnalis Televisi Indonesia. Kedua, organisasi yang berskala lokal dan sektoral, antara lain Pewarta Foto Yogyakarta (PFI), Forum Silaturrahmi Wartawan Muslim Yogyakarta, Forum Wartawan DPRD/Pemerintah, Forum Wartawan Gadjah Mada. Mengacu pada keputusan bersama 27 lebih organisasi wartawan tahun 2006 di Jakarta, ditetapkan standar organisasi wartawan. Secara utuh petikan keputusan bersama ini adalah:

Sebagai organisasi profesi, asosiasi wartawan berkewajiban mendukung dan menjaga kemerdekaan pers sesuai dengan amanat UU No. 40/1999 tentang Pers. Kebebadan pers merupakan salah satu wujud kedaulatan rakyat dan menjadi unsur penting untuk menciptakan kehidupan bermasyarakat, berbangsa dan bernegara yang demokratis. Agar mampu 
melaksanakan amanat tersebut, Dewan Pers sebagai regulator merasa perlu membuat standar pengembangan organisasi wartawan yang memiliki integritas dan kredibilitas, serta memiliki anggota yang profesional. Pelaksanaan mandat dan amanat ini bertujuan mengembangkan pers yang bebas dan yang bertanggung jawab.

Atas dasar itu, melalui inisiatif Dewan Pers, diadakan serial pertemuan perwakilan wartawan dan telah berhasil ditetapkan standar organisasi wartawan sebagai berikut:

1. Organisasi wartawan berbentuk badan hukum.

2. Organisasi wartawan memiliki Anggaran Dasar dan Anggaran Rumah Tangga sebagai organisasi profesi.

3. Organisasi wartawan berkedudukan di wilayah Republik Indonesia, dengan kantor pusat berkedudukan di ibu kota negara atau di ibu kota provinsi dan memiliki alamat kantor pusat serta kantor cabang-cabang yang jelas dan dapat diverifikasi.

4. Organisasi wartawan memiliki pengurus pusat yang sedikitnya terdiri atas ketua, sekretaris, bendahara, dan tiga orang pengurus lainnya yang tidak merangkap jabatan.

5. Organisasi wartawan, selain mempunyai pengurus pusat, juga memiliki pengurus cabang sekurang-kurangnya di sepuluh jumlah provinsi di Indonesia.

6. Organisasi wartawan memiliki mekanisme pergantian pengurus melalui kongres atau musyawarah nasional atau muktamar dalam setiap kurun waktu tertentu.

7. Organisasi wartawan memiliki anggota sedikitnya 500 wartawan dari seluruh ca- bang, yang dibuktikan dengan:

a. Kartu Pers atau Kartu Tanda Anggota dari organisasi yang bersangkutan yang masih berlaku.

b. Kartu Pers atau Surat Keterangan dari per- usahaan pers tempat ia bekerja secara tetap atau tempat ia menjadi koresponden.

c. Karya jurnalistik yang secara teratur dimuat atau disiarkan di media tempat ia bekerja secara tetap atau tempat ia menjadi koresponden.

d. Bekerja secara tetap atau menjadi kores- ponden di perusahaan pers yang memiliki media yang masih terbit atau masih melakukan siaran secara reguler.

e. Bukti-bukti tersebut (butir a-d) diverifikasi oleh Dewan Pers.

8. Organisasi wartawan memiliki program kerja di bidang peningkatan profesionalisme pers

9. Organisasi wartawan memiliki kode etik jurnalistik, yang secara prinsip tidak bertentangan dengan Kode Etik Jurnalistik yang ditetapkan oleh Dewan Pers.

10. Organisasi wartawan memiliki dewan kehormatan atau majelis kode etik jurnalistik yang bertugas:

a. Mengawasi pelaksanaan kode etik oleh para anggotanya;

b. Mengambil putusan ada tidaknya pelanggaran kode etik oleh anggotanya;

c. Menetapkan sanksi atas pelanggaran kode etik oleh anggotanya.

11. Organisasi wartawan terdaftar di Dewan Pers dan bersedia diverifikasi oleh Dewan Pers

12. Organisasi wartawan melakukan registrasi ke Dewan Pers setiap terjadi pergantian pengurus.

13. Penetapan atas standar organisasi wartawan ini dan pengawasan pelak- sanaannya dilakukan oleh Dewan Pers. 
Standar organisasi wartawan ini menjadi acuan dalam mencermati kondisi organisasi jurnalis di lapangan hingga pertengahan 2015. Meskipun yang diakui Dewan Pers hanya tiga organisasi, namun dalam keputusan bersama diatas, ada 27 organisasi wartawan yang aktif dan terlibat sehingga keberadan mereka perlu diperiksa kembali, yaitu:

1. Aliansi Jurnalis Independen (AJI) Abdul Manan

2. Aliansi Wartawan Indepensen (AWI) - Alex Sutejo

3. Asosiasi Wartawan Demokrasi Indonesia (AWDI) - OK Syahyan B

4. Asosiasi Wartawan Kota (AWK) Dasmir Ali Malayoe

5. Federasi Serikat Pewarta - Masfendi

6. Gabungan Wartawan Indonesia (GWI) - Fowa'a Hia

7. Himpunan Penulis dan Wartawan Indonesia (HIPWI) - RE Hermawan

8. Himpunan Insan Pers Seluruh Indonesia (HIPSI) - Syahril A

9. Ikatan Jurnalis Televisi Indonesia (IJTI) - Bekti Nugroho

10. Ikatan Jurnalis Penegak Harkat dan Martabat Bangsa (IJAB HAMBA) Boyke M. Nainggolan

11. Ikatan Pers dan Penulis Indonesia (IPPI) - Kasmorios, SmHk

12. Kesatuan Wartawan Demokrasi Indonesia (KEWADI) - M. Suprapto

13. Komite Wartawan Reformasi Indonesia (KWRI) - Sakata Barus

14. Komite Wartawan Indonesia (KWI) - Herman Sanggam

15. Komite Nasional Wartawan Indonesia - AM Syarifuddin

16. Komite Wartawan Pelacak Profesional (KOWAPPI) - HM Kawengian

17. Korp Wartawan Republik Indonesia (KOWRD - Hasnul Amar

18. Perhimpunan Jurnalis Indonesia (PJI) - Ismet Hasan Putro

19. Persatuan Wartawan Indonesia (PWI) - Wina Armada Sukardi
20. Persatuan Wartawan Pelacak Indonesia (PEWARPI) - Andi A. Mallarangan

21. Persatuan Wartawan Reaksi Cepat Pelacak Kasus (PWRCPK) - Jaja Suparja R.

22. Persatuan Wartawan Independen Reformasi Indonesia (PWIRI) Ramses Ramona

23. Perkumpulan Jurnalis Nasrani Indonesia (PJNI) - Ev. Robinson Togap

24. Persatuan Wartawan Nasional Indonesia (PWNI) - Rusli

25. Serikat Pers Reformasi Nasional (Sepernas) - Laode Hazirun

26. Serikat Wartawan Indonesia (SWI) Daniel Chandra

27. Serikat Wartawan Independen Indonesia (SWII) - Gunarso K

Hingga pertengahan tahun 2015, sebagaimana organisasi profesi lainnya, organisasi jurnalis mengalami dinamika pasang surut. Sekilas bisa disimpulkan, tidak semua organisasi jurnalis mampu melepas dominasi dan hegemoni rezim Orde Baru yang telah punah, dan tidak mampu melakukan transformasi menjadi organisasi profesi yang kredibel dan modern. Berbagai faktor internal dan eksternal turut mempengaruhi.

\section{Organisasi Jurnalis dan Masyarakat Sipil}

Secara idealistik, organisasi jurnalis pada hakekatnya adalah bagian dari masyarakat sipil. Mengingat kekuatan pers sebagai pilar demokrasi keempat, yaitu menjalankan kontrol kekuasaan, fungsi ini identik dengan fungsi yang dimainkan oleh masyarakat sipil, yang kritis terhadap perilaku kekuasaan. Namun, pandangan ini ternyata secara empirik tidak selalu disepakati oleh para jurnalis itu sendiri. Identifikasi diri dan organisasi sebagai elemen dari komunitas masyarakat sipil belum menjadi kesepakatan kolektif. 
Berangkat dari asumsi bahwa pers sebagai institusi sosial yang menjalankan fungsi penyediaan informasi yang mencerahkan kondisi sosial, maka organisasi jurnalis pendorong bagi terciptanya jurnalis yang berpihak pada keadialan sosial, bukan berkolaborasi terhadap aktor yang mengeksploitasi tatanan yang tidak adil. Dalam kerangka ini, organisasi jurnalis keluar dari hegemoni yang membuat institusi dan anggotanya tidak independen, kemudian secara politis mengadopsi peran-peran di masyarakat sipil.

Advokasi profesi jurnalis berbeda dengan advokasi untuk organisasi profesi atau kelompok masyarakat di mana jurnalis dalam dirinya melekat tugas pilar keempat demokrasi. Dengan menyandang gelar pilar demokrasi, pers dan jurhnalis adalah kekuatan penyeimbang di luar sistem tata negara dalam advokasi agenda bangsa. Tiga pilar demokrasi lainnya: eksekutif, legislatif dan yudikatif adalah entitas kekuatan politik formal, sedangkan jurnalis dan asosiasinya berada pada domain civil society.

Jika mencermati fenomena internasional organisasi jurnalis, maka model gerakan dan advokasi organisasi untuk anggotanya tidak terbatas peningkatan kesejahteraan, tetapi meluas menjadi tugas sejarah untuk secara langsung terlibat dalam aksi lapangan dan pembentukan opini anti korupsi dan pelanggaran HAM. Tugas normatif organisasi jurnalis ada tiga: (1) meningkatkan kapasitas intelektual dan etik profesi, (2) kompetensi profesi dan (3) kepekaan sosial kemanusiaan para anggotanya. Peneliti menempatkan kinerja organisasi jurnalis diukur menurut tiga aspek tersebut secara kualitatif maupun kuantitatif.

Jurnalis dan organisasi profesinya tidak berada dalam ruang vakum, tetapi bagian dari dinamika sosial politik. Globalisasi yang antara lain ditandai transnasionalisasi korporasi media menempatkan jurnalis dan organisasi profesinya dalam tantangan yang lebih kompleks di Indonesia. Industrialisasi komunikasi berskala besar dan multinasional yang masuk ranah pers dan monopoli kepemilikan media yang diwarnai syahwat politik kekuasaan pemiliknya, menjadi problem serius independensi disamping maraknya kekerasan wartawan. Pada isu-isu tertentu, advokasi tidak lagi efektif jika hanya berskala lokal. Jaringan internasional menjadi indikator penting suatu organisasi jurnalis yang modern.

Di era media sosial, profesionalisme jurnalis di persimpangan jalan karena jurnalisme terbuka bagi siapapun. Pada iklim ini organisasi jurnalis yang berpikir sempit, primordialistik dan dikelola tradisional akan tertinggal dan semakin tidak relevan bagi anggotanya. Politisasi media yang kemudian dikelola dalam paguyuban para jurnalis tertentu secara sporadis makin kontraproduktif bagi pembentukan model organisasi yang berwibawa.

Sejumlah penelitian telah dilakukan untuk mengetahui posisi, peran dan kotribusi organisasi jurnalis dalam advokasi kasus publik dan kasus jurnalis itu sendiri. Antara lain apa yang dilakukan organisasi jurnalis menghadapi tindak kekerasan. Riset yang dilakukan pada Aliansi Jurnalis Independen (AJD), Ikatan Jurnalis Televisi Indonesia (IJTI), dan Persatuan Wartawan Indonesia (PWI) menunjukkan adanya perbedaan pendekatan dalam menangani kasus. AJI melakukan strategi manajemen konflik melalui advokasi litigasi dan non litigasi terhadap kasus kekerasan, sementara IJTI dan PWI lebih dominan fokus pada peningkatan aspek hulu: kompetensi teknik jurnalistik para jurnalis.

Suherli (2013) dalam riset tentang peran organisasi jurnalis menjaga kebebasan pers di Indonesia dengan menggunakan metode historis, menemukan pendekatan yang berbeda antara PWI, IJTI dan AJI. PWI lebih banyak melakukan konsolidasi internal 
dảlam periode dua pengurus terakhir, menekankan pada pendidikan kompetensi. UJ $\Gamma I$ fokus manajemen isu dan berjaringan termasuk dalam advokasi regulasi UU Penyiaran, sedangkan AJI aktif dalam advokasi lapangan, antara lain melalui LBH Pers.

Diaz Bonny (2013) dalam riset nilai-nilai strategis perjuangan AJI dalam kasus pembunuhan wartawan bagi kebebasan pers di Indonesia menyimpulkan adanya nilai penting kebebasan pers dan profesionalisme sebagai pendorong advokasi. Selain itu, pada kasus Udin terdapat hambatan kebijakan hegemoni otokrasi negara, walaupun AJI sudah menggunakan berbagai cara dalam advokasinya. Peneliti menilai, nilai strategis perjuangan AJI terkait pers sebagai pilar keempat demokrasi perlu direvitalisasi.

Penulis sependapat dengan para peneliti sebelumnya agar AJI dan organisasi jurnalis lain mulai mengubah strategi perjuangan dengan mengedepankan aliansi kolektif, bekerja bersama-sama secara nasional maupun internasional, tidak menguatkan aksi sepihak. Berbeda dengan dua riset diatas, studi ini menitikberatkan pada potret menyeluruh kinerja organisasi jurnalis di Yogyakarta, tidak berskala nasional. Studi ini kami tempatkan sebagai eksplorasi umum untuk aktualisasi data, tidak memperdalam aspek tertentu.

\section{Dua Model Organisasi}

Penelitian dengan topik: Potret Organisasi Jurnalis Paska Orde Baru di Yogyakarta berlangsung selama tiga bulan, yaitu bulan Mei hingga Juli 2015. Penulis dibantu dua orang asisten penggali data lapangan, yaitu Rochimawati dan Wita Ayodyaputeri, keduanya adalah jurnalis aktif. Dalam tiga bulan telah dilakukan penggalian data melalui wawancara dengan pengurus/pengelola organisasi jurnalis, observasi ruang/kawasan berkumpul para anggotanya dan pengumpulan dokumen yang tersebar di media online, cetak dan sejenisnya. Informasi juga digali melalui database sejarah media di Yogyakarta.

Berikut ini data responden penelitian yang berhasil ditemui:

\begin{tabular}{|c|c|c|c|c|c|}
\hline $\mathrm{No}^{1}$ & Organisasi & Sumber & Alamat & Berdiri & Anggota \\
\hline$\overline{1}$ & $\begin{array}{c}\text { Persatuan Wartawan } \\
\text { Indonesia (PWI) }\end{array}$ & $\begin{array}{c}\text { Primaswolo } \\
\text { Sudjono }\end{array}$ & J1. Gambiran & 1945 & 400 \\
\hline 2 & $\begin{array}{c}\text { Aliansi Jurnalis } \\
\text { Independen } \\
\text { Yogyakarta (AJ) }\end{array}$ & $\begin{array}{l}\text { Hendrawan } \\
\text { Setiawan }\end{array}$ & Jl. Pakel Baru & 1994 & 46 \\
\hline $\begin{array}{l}3 i \\
\end{array}$ & $\begin{array}{l}\text { Forum Pewarta Foto } \\
\text { Indonesia (PFI DIY) }\end{array}$ & Hamid & $\begin{array}{l}\text { Detikcom } \\
\text { Baciro }\end{array}$ & 1998 & 34 \\
\hline 4 & $\begin{array}{c}\text { Forum Wartawan } \\
\text { Universitas Gadjah } \\
\text { Mada }\end{array}$ & Wijayanti & $\begin{array}{c}\text { Kantor Pusat } \\
\text { UGM }\end{array}$ & 1986 & 33 \\
\hline 5 & $\begin{array}{c}\text { Forum Wartawan } \\
\text { DPRD } \\
\text { Provinsi DIY }\end{array}$ & $\begin{array}{l}\text { Agung } \\
\text { Raharjo }\end{array}$ & $\begin{array}{l}\text { Sekretariat } \\
\text { DPRD DIY }\end{array}$ & 2013 & - \\
\hline 6 & $\begin{array}{c}\text { Forum Pewarta DPRD } \\
\text { Kota Yogyakarta }\end{array}$ & Ardhi & $\begin{array}{l}\text { Sekretariat } \\
\text { DPRD Kota }\end{array}$ & 2003 & 20 \\
\hline
\end{tabular}


Dari enam responden yang mewakili organisasi yang berbeda tersebut diatas, dua hal bisa dikemukakan. Pertama, terdapat fenomena pengurangan jumlah organisasi jurnalis yang masih beroperasi aktif, jika dibandingkan masa awal pasca Orde Baru runtuh. Ikatan Jurnalis Televisi Indonesia dan PWI Reformasi tidak beroperasi, sedangkan beberapa organisasi yang dikelola penyiar radio dan TV dan sebelumnya diinisiasi secara individual tidak lagi memiliki aktifitas yang terkoordinir. Kedua, muncul organisasi yang lahir sebagai varian baru dari organisasi sebelumnya, yaitu Perhimpunan Jurnalis Indonesia (PJI), sebelumnya adalah PWI Reformasi. Namun keberadaan sekretariatnya sulit dilacak.

Dari segi formula keanggotaan dalam organisasi, terdapat dua model di Yogyakarta. Pertama, organisasi solid yang memiliki badan hukum, AD/ART, berbasis kepada kekuatan anggota, memiliki struktur organisasi hirarkis hingga level pusat yaitu PWI, AJI dan Pewarta Foto Indonesia (PFI). Kedua, organisasi yang bersifat 'paguyuban' cair, dibentuk tidak murni berdasarkan kebutuhan anggota dan profesionalisme, tetapi didorong motivasi situasional atau melekat pada institusi eksternal selaku penyandang dana atau pusat kegiatan liputan dari para jurnalis. Selengkapnya, berikut ini diuraikan temuan penelitian dalam empat tematik yang menggambarkan situasi empirik organisasi jurnalis.

\section{Manajemen Organisasi}

Dilihat pada tiga aspek, (1) adanya sekretariat yang permanen dan dikelola secara profesional (merekrut staff harian, menggelar rapat rutin organisasi serta mengeluarkan kartu anggota), (2) ada kepengurusan yang dipilih secara regular dan (3) ada aktifitas organisasi yang sudah berlangsung lebih dari 15 tahun pasca 1998, Aliansi Jurnalis Independen dan Persatuan Wartawan Indonesia merupakan dua organisasi yang relatif memenuhi dan mapan karena memiliki ketiga kriteria diatas. Keduanya memiliki badan hukum, AD/ART telah aktif melakukan rekruitmen anggota dengan mekanisme dan proses seleksi yang terpola, meskipun tetap mengalami perubahan. Mekanisme pergantian kepengurusan berjalan di setiap periode yang disepakati. Dari segi jumlah anggota termasuk yang memperoleh sertifikasi, maka PWI terbanyak, disusul AJI Yogyakarta dan organisasi lainnya.

Sedangkan Forum Pewarta Foto (PFI) merupakan organisasi baru yang masih mencari format kelembagaan yang tepat. Sekretariat masih menumpang pada kantor redaksi Detikcom Yogyakarta. Organisasi lainnya: forum wartawan DPRD Provinsi dan Kota Yogya, Forum Wartawan Universitas Gadjah Mada tidak memiliki sekretariat tersendiri dan kegiatannya tidak terencana, sporadis, mengacu kepentingan dari institusi yang melekat seperti DPRD dan UGM. Sedang forum silaturrahmi wartawan Muslim (FSWM) Yogyakarta sudah tidak aktif sejak 3 tahun terakhir. Model rekruitmen anggota dan pergantian kepengurusan tidak terpola. Bahkan pengelola utamanya tidak murni dari jurnalis, tetapi kepala Humas/Kepala sekretariat bidang Humas dan Protokol kantor birokrasi setempat. Kelompok ini jika merujuk kepada ketentuan Dewan Pers, hampir pasti tidak masuk kategori sebagai organisasi jurnalis dengan standar yang berlaku secara nasional, mereka lebih mirip paguyuban.

\section{Sumber Dana}

Sumber dana bagi organisasi dan bagaimana pelaporan menurut ketentuan UU No. 14/2008 tentang Keterbukaan Informasi Publik merupakan salah satu indikator independensi dan transpransi kepada publik. Ada empat jenis sumber dana organisasi jurnalis: Pertama, iuran individu yang dipungut bulanan dari setiap anggota. Ini sumber dana paling ideal untuk menjaga independensi organisasi sekaligus membuktikan adanya kepedulian anggota. Kedua, dana hibah 
program kerja yang diperoleh dari sumber-sumber pendanaan di dalam dan luar negeri. Ketiga, sponsorship kegiatan dari lembaga negara/pemerintah dan swasta. Keempat, sumbangan individu/lembaga luar secara sukarela páda kegiatan tertentu.

Secara umum terdapat bersumber dari iuran atau dana internal organisasi tidak berkontribusi signifikan, tidak lebih dari 10 persen kebutuhan operasional organisasi. Proses pengumpulan iuran tidak lancar dan tidak terkoordinir dengan baik. Baik AJI, PWI, PFI dan organisasi lain mengandalkan sumber dana eksternal dengan beragam variasi melalui pengajuan proposal. Jika AJI Yogya sangat dominan dengan sumber dari lembaga donor internasional, PWI sangat dominan dengan sumber dana dari pemerintah pusat/daerah, terutama hibah APBD//APBN. Sedang PFI mengandalkan partisipasi sponsor di setiap kegiatan tahunan atau sumbangan pribadi anggota.

Forum

jurnalis

DPRD

Próvinsi/Kota Yogya dan forum serupa di UGM 100 persen mengandalkan sumber biaya kegiatan dari Humas lembaga setempat dengan mekanisme taken for granted alias sudah disiapkan dalam anggaran belanja tahunan. Dari segi kepastian dan regularitas pembiayaan, kelompok ini lebih terjamin, ketimbang organisasi lain seperti PWI, AJI dan PFI, namun tingkat partisipasi saat pengambilan keputusan relatif rendah dan pagu anggaran yang dirancang tidak selamanya sesuai dengan kebutuhan organisasi. Kecuali Fortagama, alokasi dana forum jurnalis DPRD/SKPD pemerintah, lebih ditujukan memenuhi kebutuhan individu jurnalis yang rutin meliput kegiatan, tidak otomatis menopang organisasi yang menaungi keberadaan perkumpulan jurnalis setempat.

\section{Terkait}

laporan

pertanggungjawaban keuangan, selain ke anggota, semua organisasi yang diteliti belum memiliki mekanisme keterbukaan informasi publik padahal sumber dana yang dikelola mayoritas dari dana publik (dana lembaga luar negeri dan dana pemerintah: APBN/APBD). Dalam website PWI, AJI dan PFI, tidak terdapat kolom khusus pelaporan keuangan yang sesuai ketentuan dalam UU No. 14 tahun 2008 tentang KIP sebagai badan publik. Masih ada persepsi umum di kalangan pengelola organisasi jurnalis bahwa laporan keuangan lebih tepat dilakukan oleh instansi pemberi dana.

\section{Program Kerja}

Kegiatan organisasi yang bersifat rutin dan insidental menjadi pilar kehidupan sebuah lembaga. Ada 2 bentuk kegiatan: Pertama, kegiatan rutin yang digelar setiap bulan atau tahun dalam rangka menunjukkan eksistensi diri. Kedua, kegiatan insidental sebagai bagian dari advokasi untuk anggota dan bagian dari kolaborasi dengan pihak eksternal. Dua organisasi yaitu AJI dan PWI telah memenuhi kedua kriteria, namun tidak pada organisasi lain. Adapun yang membedakan antara PWI, AJI dan organisasi lain adalah pada pilihan fokus orientasi dan bentuk. Dari 3 bentuk kegiatan, (1) peningkatan profesionalisme anggota, (2) advokasi untuk kesejahteraan anggota (3) kampanye terhadap isu-isu publik, terdapat perbedaan yang signifikan. AJI fokus peningkatan profesionalisme, implementasi prinsip independensi seperti penegakan etik anti amplop, pelatihan penguatan wawasan jurnalistik isu isu khusus (Gender, lingkungan, HAM) dll, PWI fokus peningkatan profesionalisme melalui pelatihan berjenjang, dan seminar terkait profesionalisme jurnalistik secara umum. Sementara itu Pewarta Foto Indonesia secara terbatas menggelar pelatihan untuk anggotanya.

Pada konteks isu peningkatan kesejahteraan, AJI tampak menonjol untuk kampanye penguatan hak-hak pekerja sebagai buruh media, melalui pelatihan dan publikasi upah minimum jurnalis serta advokasi kasus perburuan di media melalui LBH Pers yang lahir dari rahim AJI setempat. Sedangkan PWI mengambil jalan kampanye isu secara umum melalui pemberitaan dan lobi pimpinan media tempat para anggotanya 
bekerja. Organisasi lain tidak mengambil inisiatif isu ini dengan alasan sudah terwakili di AJI dan PWI. Dari segi visi dan misi, baik PWI, AJI maupun PFI memiliki kesamaan soal ini.

Terkait isu publik diluar jurnalisme, terobosan dilakukan Forum Pewarta Foto dengan menggelar dua kali pameran Jogja Berhenti Nyaman (2013) dan Ayo Ngguyu (2014) yang menonjolkan kepedulian terhadap permasalahan tata kota Yogyakarta, yang kian semrawut dan tidak ramah bagi penghuninya. Dalam advokasi isu publik terutama kasus pembunuhan wartawan Fuad Muhammad Syafruddin di Bantul, seluruh organisasi jurnalis yang diteliti seia sekata, memiliki kepedulian yang sama dan membuat program rutin. Program advokasi dan kampanye kasus Udin misalnya digelar AJI dan PWI Yogya dengan seminar, kunjungan ke makam, publikasi pernyataan sikap dan aksi terbuka teatrikal.

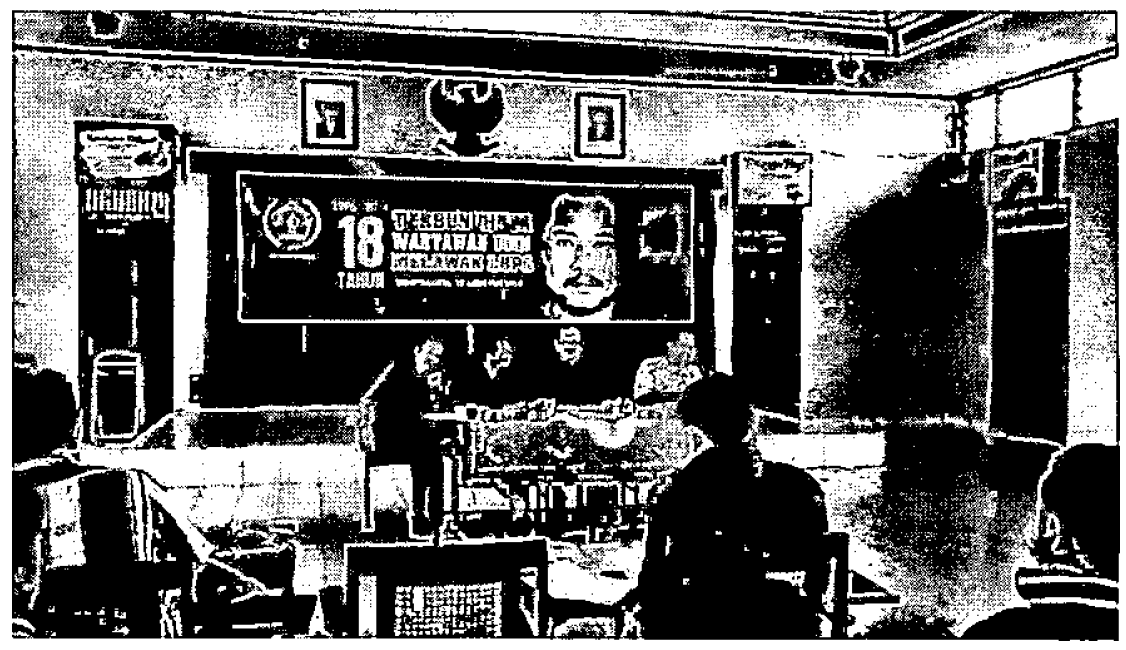

Foto 1: PWI Yogya konferensi pers terkait 18 Tahun Kasus Udin

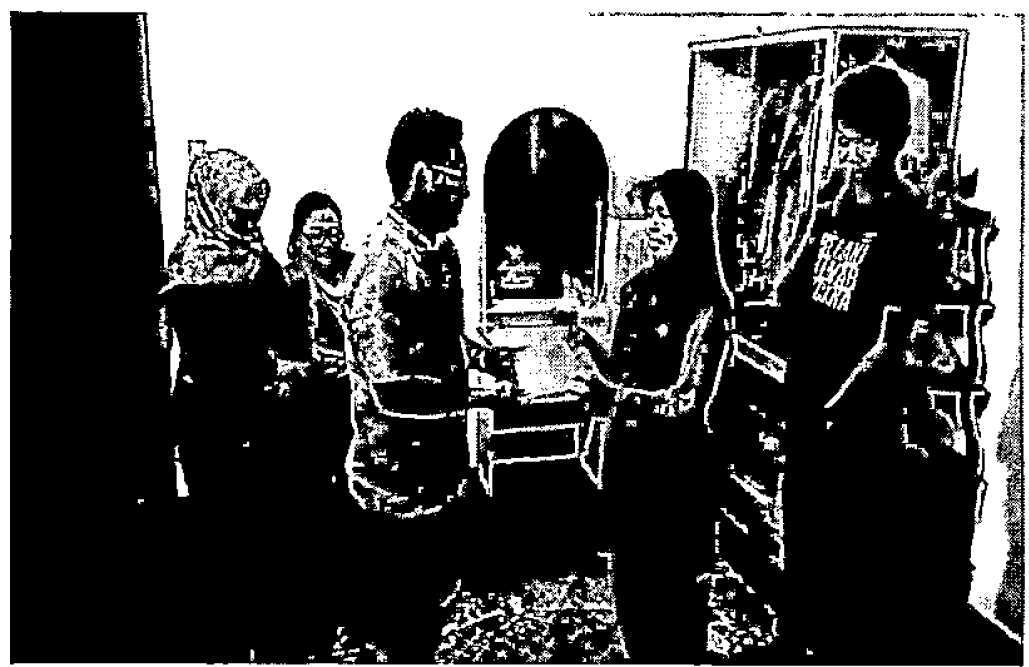

Foto 2: AJI Yogya Menyerahkan Bingkisan ke Marsiyem, istri Udin

Menarik dicatat, AJI Yogya memiliki tradisi terlibat secara organisasi mengavokasi isu jsu publik seperti anti- korupsi, pro-lingkungan yang sehat seperti aksi Jogja Berdaya beraliansi dengan elemen masyarakat sipil lain di 
Yogyakarta. Pilihan ini tidak dilakukan oleh organisasi jurnalis lain yang diteliti. Kolaborasi antara AJI (organisasi dan anggota) dengan masyarakat sipil (NGO dan Ormas) yang lebih dari sekedar relasi jurnalis-sumber berita di di DIY lebih intensif dibandingkan PWI ataupun PFI. Strategi melibatkan diri dalam komunitas masyarakat sipil pada advokasi korupsi dana hibah PERSIBA Bantul menjadi ciri yang menunjukkan pemihakan serius atas kepentingan publik. Dalam advokasi kasus Udin, sejak tahun 2013 AJI bersama elemen masyarakat sipil menggagas aksi rutin bulanan setiap tanggal 16 di depan Markas Polda DIY dan Istana Negara, seperti gambar berikut:

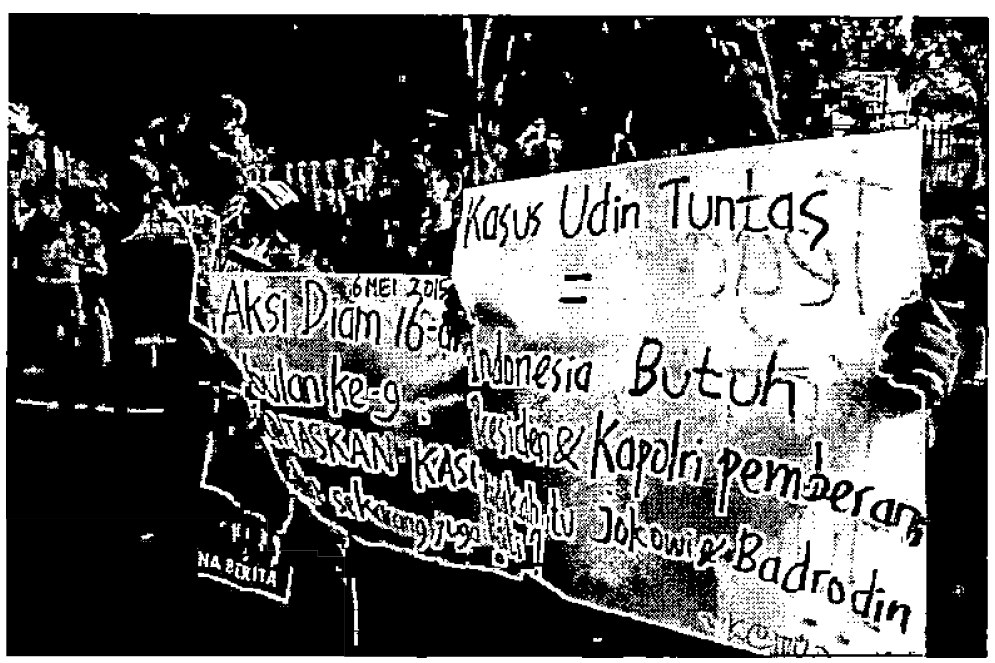

Foto 3: Aksi setiap 16 Agustus oleh para aktifis di Yogyakarta

\section{Prinsip Independensi}

Independensi jurnalis dan organisasinya tidak diukur melalui pernyataan sikap pribadi atau pernyataan ke publik yang rutin. Ia harus terkonfirmasi dari perilaku anggota, sumber dana organisasi dan komitmen menjaga posisi lembaga dari faktor faktor yang berpotensi destruktif. Dilihat dari sumber dana organisasi, prinsip independensi atas lembaga pemerintah sebagai pihak yang harus dikontrol oleh jurnalis, hampir pasti tidak bisa dilakukan jikà organisasi jurnalis mengandalkan dana pemerintah seperti PWI. Ketergantungan dukungan dana dari donor asing yang kerap menentukan agenda isu untuk dijalankan organisasi AJI, termasuk di Yogyakarta juga rentan mengurangi independensi terutama atas kebijakan negara donor yang eksploitatif atas sumberdaya ekonomi politik lokal.

Selain itu, kualitas independensi profesional ditentukan oleh para anggota yang secara tegas menolak pemberian yang mempengaruhi berita. Dalam konteks ini, sikap tegas dan jelas hanya ditunjukkan AJI Yogya dengan melarang menerima amplop, mendukung upaya penguatan independensi anggotanya sebagai pemantau kekuasaan, sikap ini tidak ditunjukkan organisasi jurnalis lain di Yogyakarta. Secara singkat, independensi organisasi jurnalis masih menjadi problem serius, disamping independensi para anggotanya.

\section{Penutup}

Penelitian ini menyimpulkan beberapa hal sebagai berikut:

1. Pertama, eksistensi organisasi jurnalis di Yogyakarta mengalami dinamika melalui dua model format organisasi: formal dan paguyuban, yang mencerminkan dualisme pandangan, orientasi sikap jurnalis terhadap urgensi berorganisasi, sekaligus relasi organisasi dengan para pihak terkait di kawasan ini. 
2. Kedua, manajemen organisasi terutama regularitas program dan keuangan sebagai pilar menjaga kelangsungan organisasi dan independensi belum mendapat perhatian serius terutama pada aspek partisipasi iuran anggota sebaga bentuk rasa memiliki dan menjaga independensi dari intervensi eksternal.

3. Ketiga, bentuk kegiatan yang bersifat praktis, bertumpu pada profesionalisme teknis masih dominan,orientasi kepentingan yang masih berbeda diantara organisasi jurnalis, membuat tidak tampak formula yang menyatukan bersama organisasi yang ada untuk menjadi kekuatan penyeimbang demokrasi lokal di DIY.

Beberapa rekomendasi yang dapat disampaikan adalah:

1. Upaya mendasar membangun organisasi yang independen harus menjadi fokus, antara lain mengurangi ketergantungan pendanaan dari lembaga eksternal di satu sisi, dan memperkuat basis advokasi bersama pada isu isu publik disisi lain.

2. Pertemuan kolektif organisasi jurnalis di DIY perlu untuk menyatukan langkah bagi penciptaan iklim kebebasan pers dan iklim organisasi yang makin diminati anggota, generasi baru jurnalis di era media sosial yang pola pikirnya lebih kritis, independen dan humanis. Kolaborasi antar berbagai organisasi jurnalis diperlukan untuk dua hal. Pertama, secara internal untuk meminimalisir makin melebarnya penyimpangan bentuk organisasi jurnalis yang yang menurunkan martabat pers dan jurnalis sebagai pilar keempat demokrasi. Kedua, secara eksternal untuk memperbesar energi kreatif bagi penguatan masyarakat sipil dalam proses demokratisasi.

3. Penelitian lanjutan oleh peneliti lain diperlukan untuk memotret kinerja organisasi jurnalis dalam isu tertentu, misalnya isu anti korupsi, dan dengan memperiuas cakupan wilayah penelitian pada tingkat nasional bahkan regional. 


\section{Daftar Pustaka}

Bonny, Diaz. (2013). Nilai-Nilai Strategis Perjuangan Aliansi Jurnalis Independen dalam Kasus Pembunuhan Wartawan bagi Kebebasan Pers di Indonesia. Fakultas Ilmu Komunikasi, UNPAD. Bandung.

Dewan Pers. (2011). Kriteria dan Tata Cara Menetapkan Organisasi Wartawan sebagai Lembaga Penguji Standar Kompetensi Wartawan. Dewan Pers, Jakarta.

Peter, Ada Sonia, (2013), The Elements of Journalism, Book Review, Convenant Journal of Communication, Vol. 1, No. 2, November 2013

Harymurti, Bambang, (2014), Konsep Pers Profesional Menurut UU Pers dan KEJ, Paper pada Workshop Media di Jakarta, 10 Juni 2014

Masduki. (2004). Kebebasan Pers dan Kode Etik Jurnalistik. UII Press. Yogyakarta.
Pasaribu, dkk. (1998). Menuju Masyarakat Kewargaan. LP3Y, Yogyakarta.

Suherli, F. (2013). Peranan Organisasi Wartawan dalam Menjaga Kebebasan Pers di Indonesia, Fakultas Ilmu Komunikasi, UNPAD. Bandung.

Sutopo, HB. (2002). Metodologi Penelitian Kualitatif. UNS Press. Surakarta.

Siregar, A. (2000). Media Pers dan Negara: Keluar dari Hegemoni. Jurnal Ilmu Sosial dan Ilmu Politik UGM, Volume 4 Nomor 2, Nopember 2000.

Thamrin A. T. (1999). Jurnalisme Berperspektif Gender. Mukhotib MD, ed. PMII Yogyakarta. Yogyakarta.

Undang-Undang No. 40 Tahun 1999 tentang Pers

Undang-Undang No. 9 Tahun 1998 tentang Kebebasan Berpendapat di Muka Umum 
Jurnal komunikasi, Volume 10, Nomor 1, Oktober 2015 